УДК 378.046-021.64

https://doi.org/10.33296/2707-0255-10(19)-13

https://orcid.org/0000-0002-1272-0422

КАРОЛОП ОЛЕНА,

ст. викладач Навчально-наукового

інституту

Національного університету культури і

мистецтв,

Київ, Україна,

\title{
Інноваційні підходи до формування та розвитку професійної компетентності майбутніх бакалаврів готельно-ресторанної справи
}

Анотація. У статті розкрито проблему інноваційних підходів щодо професійної підготовки бакалаврів, розглядаються інноваційні методи навчання, які використовуються у системі сучасного освітнього процесу, визначені особливості засобів, форм і методів інноваційного навчання, розкривається специфіка їх використання в освітньому процесі.

Акцентується увага на інноваційних підходах щодо формування професійно активних бакалаврів готельно-ресторанної справи через використання інтерактивних методів навчання у ЗВО. Інтерактивні заняття у формі тренінгів (позиційно-рольових) активізують розвиток професійної креативності, мобільності студентів, реалізують практику випереджувальної фахової підготовки бакалаврів, зроблено акцент на необхідності використання мультимедії як засобу й кейс-технології, як методу навчання Професійна компетентність розглядається як засіб, як спосіб і як результат освоєння новацій бакалаврами готельно-ресторанної справи, які свідомо долучаються до інноваційної діяльності і відповідно підготовлені до неї.

Упровадження інноваційних технологій в освітній процес, зокрема у ході дистанційного навчання, сприяє підвищенню ефективності освіти, а як наслідок, якіснішій підготовці майбутніх фахівців.

Ключові слова: Інноваційні підходи, професійна компетентність, бакалаври, готельно-ресторанна справа, інноваційні технології, дистанційне навчання.

Постановка проблеми. Підготовка фахівців 3 готельно-ресторанної справи повинна здійснюватися 3 урахуванням сучасних вимог до гостинності. Персонал повинен бути ввічливим, комунікабельним і доброзичливим до споживачів. Щоб задовольнити ці потреби, необхідно прикласти багато зусиль 
Електронне наукове фахове видання «Адаптивне управління: теорія і практика.

Серія «Педагогіка»

Випуск 10(19), 2020

для підготовки фахівців готельно-ресторанної справи. Фахівців готують до організаційно-управлінської, господарської, комерційної, інвестиційної та науково-дослідної діяльності у сфері ресторанного, готельного господарства та виставкової діяльності [5].

Світовий ринок гостинності на разі переживає підйом, кожен день 3'являється все більше нових послуг. Про це ми дізнаємось з соціальних мереж та Інтернету. Більшість українців протягом дня передивляться різні фото, відео закордонних та вітчизняних кухарів, барменів, рестораторів. Там можна побачити незвичні для нас способи обслуговування, приготування їжі, коктейлів, лимонадів та іншого.

Покращення у сфері обслуговування безпосередньо залежить від застосування інновацій. Варто зазначити, що оскільки зараз держава переживає фінансову кризу, то і рівень сервісу в закладах харчування $є$ далеко не найкращим. Тому для того, щоб привернути увагу потенційних клієнтів, керівники готелів, ресторацій та кафе впроваджують у діяльність закладів нові інноваційні технології.

За оцінками експертів готельно-ресторанного ринку, саме від ефективності роботи працівників, а не від факторів виробництва залежить формування лояльності відвідувачів i, як результат, економічний розвиток підприємств готельно-ресторанної індустрії в цілому. Тому виникає потреба у детальнішому вивченні тенденцій та інновацій у формуванні кадрового забезпечення клієнтоорієнтованого сервісу та розробці шляхів його постійного розвитку.

Мета статті дослідити особливості інноваційних технологій у процесі формування професійної компетентності майбутніх бакалаврів готельноресторанної справи та розкрити важливість ролі інноваційних технологій у процесі їх навчання.

Виклад основного матеріалу. Питанням функціонування та розвитку готельно-ресторанного господарства приділили значну увагу вітчизняні та закордонні науковці, а саме: М. Мальська, Л. Агафонова, В. Архіпов, М. 
Електронне наукове фрахове видання «Адаптивне управління: теорія і практика.

Серія «Педагогіка»

Випуск 10(19), 2020

Кабушкін, Г. П'ятницька, С. Блайні.

Проаналізувавши літературні джерела, наукові публікації, Інтернетджерела можемо констатувати, що професійна діяльність фахівця у сфері послуг полягає у здатності:

- володіти базовими загальними знаннями із готельного і ресторанного господарства;

- аналізувати сучасні тенденції розвитку сфери;

- організовувати колективну працю з метою надання послуг;

- проектувати технологічний процес виробництва продукції і складати необхідну нормативну документацію;

-здійснювати підбір технологічного устаткування та обладнання, визначати площі приміщень;

- здійснювати оперативний контроль якості надання послуг;

- визначати закономірності та тенденції їх розвитку, оцінювати вплив факторів внутрішнього та зовнішнього середовища на функціонування готельно-ресторанного господарства;

- швидко та ефективно розв'язувати широке коло проблем, що виникають під час професійної діяльності, шляхом практичного використання комунікаційних навичок, спеціалізованих знань та сучасних технологій;

- забезпечити охорону праці та техніки безпеки;

- розробляти короткострокові і середньострокові плани діяльності закладів готельного та ресторанного господарств;

- досконало володіти сучасною діловою українською та іноземними мовами професійного спрямування та інш.

Фахова підготовка майбутніх фахівців $є$ важливим кроком у формуванні професіоналів. У цей період формується світосприйняття під кутом майбутньої професії, відшліфовуються уміння і навички, набувається первинний досвід [2].

Підготовка майбутніх фахівців залежить від якості розроблених кваліфікаційних характеристик, які $є$ основними вимогами до професійних 
Електронне наукове фахове видання «Адаптивне управління: теорія і практика.

якостей, знань і умінь для успішного виконання професійних обов'язків.

Стандарт вищої освіти галузі знань 24 «Сфера обслуговування» спеціальності 241 Готельно-ресторанна справа першого (бакалаврського) рівня вищої освіти затверджено та введено в дію Наказом Міністерства освіти і науки України від 04.03.2020 № 384.

Відповідно до вищеназваного документа, цілі навчання повинні бути зреалізовані завдяки формуванню загальних і фахових компетентностей, що стануть достатніми в майбутньому для успішного розв’язання фахових спеціалізованих складних завдань i практичних проблем в умовах комплексності й невизначеності умов у сфері готельного та ресторанного бізнесу.

Для отримання якісної освіти сьогодення та реалізації особистісного потенціалу мають бути створені необхідні умови, такі як: уміння генерувати нові ідеї, критичність мислення, здатність приймати нестандартні рішення та нести за них відповідальність, уміння працювати в команді, уміння інтегруватись у сучасне суспільство, моделювати освітні ситуації. Вирішенню i застосуванню поданих умов буде сприяти їх реалізація.

Нові інноваційні освітні технології на основі комп'ютерних засобів дають можливість значно підвищити ефективність. Інновації у навчальній діяльності пов'язані з активним процесом створення, поширення нових методів і засобів для вирішення дидактичних завдань підготовки фахівців у гармонійному поєднанні класичних традиційних методик та результатів творчого пошуку, застосування нестандартних, прогресивних технологій, оригінальних дидактичних ідей і форм забезпечення освітнього процесу [7].

Використання інноваційних технологій у навчальному процесі вищої школи є предметом досліджень вітчизняних і зарубіжних вчених. Проблемам інноваційної діяльності в освітній сфері було присвячені праці вчених Л. Ващенко, Н. Артикуца, М. Поташника, В. Журавльова, А. Ніколса, Г. Герасимова, Л. Ілюхина, І. Беха, Л. Даниленко, І. Дичківська, Н. Дубової. 
Електронне наукове фахове видання «Адаптивне управління: теорія і практика.

Освітні інновації полягають в сучасному моделюванні, організації нестандартних лекційно-практичних, семінарських занять; індивідуалізації засобів навчання; розробці нової системи контролю оцінки знань; застосуванні комп'ютерних, мультимедійних технологій; навчально-методичної продукції нового покоління. Серед сучасних технологій навчання, можно виділити: особистісно-орієнтовані, інтеграційні, колективної дії, інформаційні, дистанційні, творчо-креативні, модульно-розвивальні тощо[3].

В освітній практиці диверсифікація навчальних технологій дозволяє активно і результативно їх поєднувати через модернізацію традиційного навчання та переорієнтацію його на ефективне, цілеспрямоване. За такого підходу акцентується на особистісному розвитку майбутніх бакалаврів готельно-ресторанної справи здатності оволодівати новим досвідом творчого і критичного мислення, рольового та імітаційного моделювання пошуку вирішення навчальних завдань та ін. [3]. Згідно із науковими положеннями загальноприйняті методи викладання можна класифікувати за такими ознаками: види навчальних робіт студентів (усні, письмові; аудиторні, самостійні, позааудиторні); загальні (колективні, групові, індивідуальні та ін.); джерело одержання знань і формування навичок і вмінь (лекція, аналіз документа, робота із нормативною базою, використання наочних засобів, інтернет-ресурсів тощо); ступінь самостійності та характер участі студентів у освітньому процесі (активні, інтерактивні, пасивні); рівень усталеності та новизни (традиційні, класичні, нестандартні, новаторські), авторство (оригінальні, авторські, загальні, дидактичні) та ін. У сучасній методиці викладання найбільш прийнятною виявилася класифікація, побудована на дієвому підході до навчання. Згідно з нею існують методи:

а) які забезпечують опанування навчального предмета (словесні, візуальні, практичні, репродуктивні, проблемно-пошукові, індуктивні, дедуктивні);

б) які стимулюють та мотивують навчально-наукову діяльність (навчальні дискусії, проблемні ситуації, професійно-орієнтовані ділові ігри, творчі 
Електронне наукове фрахове видання «Адаптивне управління: теорія і практика.

завдання, пошук і дослідження, експерименти, веб-квести, конкурси, виставки, вікторини тощо);

в) методи контролю і самоконтролю у навчальній діяльності (опитування, залік, іспит, контрольна робота, тестові завдання, портфоліо, питання для самоконтролю, у т. ч. через комп’ютерні освітні системи).

На сьогодняшньому ринку освітніх послуг ефективними, дієвими, доцільними для використання у сучасних умовах інформатизації вищої школи $є$ інноваційні активні та інтерактивні методики навчання. Оскільки суттєво зростає творча компонента освіти, активізується роль усіх учасників навчального процесу, зміцнюється творчо-пошукова самостійність студентів, особливої актуальності набули концепції проблемного та інтерактивного навчання, пов'язаного з використанням комп'ютерних систем. Під час такого освітнього процесу майбутні бакалаври готельно-ресторанної справи можуть комунікувати з викладачами в он-лайн, вирішувати творчі, проблемні завдання, моделювати ситуації, створювати кейс-методи, методи проектів, включаючи аналітичне і критичне мислення, знання, пошукові здібності. Зокрема, сучасна методика викладання спеціальних дисциплін має певний арсенал різноманітних способів, прийомів і засобів навчання, як загальнодидактичних (застосовуються у викладанні будь-яких навчальних предметів), так і галузево-дидактичних (віддзеркалюють специфіку конкретної навчальної дисципліни або низки споріднених дисциплін) [2]. Серед інноваційних методик викладання, інтерактивних методів, форм і прийомів, що найчастіше використовуються в навчальній роботі з майбутніми бакалаврами готельно-ресторанної справи, слід зазначити такі, як аудіовізуальний метод навчання; створення та використання «інтелект-карти»; бриколаж, брейнстормінг («мозковий штурм»); воркшоп (workshop-майстерня на отримання динамічного знання); квест-технології; технології сторітеллінгу; діалог Сократа (сократів діалог); «дерево рішень»; ділова (рольова) гра (студенти перебувають у ролі експерта, постачальника, замовника, виробника, відвідувача); майстер-класи; метод аналізу і діагностки 
Електронне наукове фахове видання «Адаптивне управління: теорія і практика.

ситуації; метод інтерв’ю (інтерв’ювання); метод проектів; моделювання; публічний виступ; презентації, тренінги індивідуальні та групові; вебквест(сайт в Інтернеті) та ін.[1,4,7,8].

Із впровадженням дистанційного навчання майже всі ЗВО уже сьогодні застосовують технологію онлайн-семінару під назвою «вебінар», який демонструє порівняльні таблиці, презентації, відеоролики тощо. За допомогою інтернет-технологій вебінар зберіг головну ознаку семінару - інтерактивність, яка забезпечує моделювання функцій доповідача, слухача, що працюють інтерактивно, комунікуючи разом за сценарієм проведення такого семінару [8]. Ученими-практиками також розроблена й експериментально перевірена модель організації самостійної роботи студентів заочної форми навчання, яка передбачає три етапи:орієнтовний (підготовчий), діяльнісний (виконавчий), контрольно-корекційний (заключний). Модель спрямована передусім на забезпечення підвищення рівня індивідуально-психологічної готовності студентів до самостійного навчання, оволодіння майбутніми рестораторами, готельєрами 3 відповідними кваліфікаціями, набуття вмінь $і$ навичок професійної роботи, розвиток професійно значущих якостей особистості. Крім того, розкриваючи активні методи навчання майбутніх бакалаврів готельноресторанної справи, необхідно також приділити увагу питанням соціальнопсихологічного тренінгу, в якому основним принципом виступає активна позиція кожного його учасника. Сутність і класифікація тренінгу, основні види вправ і процедур, етапи тренінгової роботи зводяться до «зворотного зв’язку», який полягає у висловленні кожним учасником власної думки з окремих питань навчального заняття. Включення в освітній процес активних форм навчання, у тому числі психологічних тренінгів, суттєво впливає на розвиток професійних та особистісних якостей майбутнього фахівця. Сучасні системи інтерактивного навчання спеціальним дисциплінам доцільно розглядати як комплекси певним чином впорядкованих технологій (у т. ч. і технологій дистанційного навчання), що мають відповідну специфіку та логіку. У той же час при налагодженні 
Електронне наукове фахове видання «Адаптивне управління: теорія і практика.

зв’язку викладач - студент за допомогою онлайн-комунікації в інформаційному освітньо-науковому середовищі університетів необхідні суттєві консолідовані дії кафедр, інформаційних центрів, лабораторій, бібліотек для його наповнення якісними проблемно-орієнтованими ресурсами, як наслідок, забезпечення здобуття знань. Так, на фокус-опитуванні майбутніх бакалаврів готельноресторанної справи «чи допомагають електронні ресурси у вивченні фахових дисциплін» - 91 \% респондентів відповіли, що електронні навчальні комплекси, електронні підручники, інші навчально-методичні матеріали і віртуалізовані засоби є важливими в дистанційній освіті. Сучасний зміст освіти має орієнтуватися на використання інформаційних технологій, поширення інтерактивного, електронного навчання 3 доступом до цифрових ресурсів та інтелект-навчання для майбутнього [7].

Упродовж останнього десятиріччя в Україні відбувається перехід до цифрової економіки, освіти та суспільства. Це підтверджує прийняття таких нормативно-правових документів, як Положення про електронні освітні ресурси, Положення про дистанційне навчання, Положення про електронний підручник, Положення про Національну освітню електронну платформу, Концепція розвитку цифрової економіки та суспільства на 2018-2020 роки та ін. $[8,9,11,13]$

У зв’язку з цим перед сучасними викладачами ЗВО постало завдання навчаючись i перебудовуючись залежно від нових вимог часу, навчати i готувати до майбутньої діяльності студентів.

Як відомо, технологічна еволюція системи сучасних ЗВО відбувалася досить повільними темпами, але суттєвим викликом для всіх без винятку стала пандемія коронавірусу. Впродовж одного-двох днів стало зрозуміло, що зміни неминучі.

У відповідь на поширення пандемії уряд країни почав вживати заходів та запровадив режим надзвичайної ситуації. У цих умовах МОН України підготувало Наказ «Про організаційні заходи для запобігання поширенню 
Електронне наукове фрахове видання «Адаптивне управління: теорія і практика.

Серія «Педагогіка»

Випуск 10(19), 2020

коронавірусу COVID-19» від 16.03.2020 № 406, а заклади освіти всіх рівнів усвідомили, що необхідно діяти.

Таким чином, перед закладами освіти постало завдання - організувати альтернативний до очного навчання освітній процес, а це вимагало негайного виконання низки завдань:

- формування банку електронних скриньок педагогів, студентів;

- формування банку мобільних номерів, що мало відповідати всім вимогам щодо захисту персональних даних;

- добір системи засобів для здійснення дистанційного навчання;

- перевірка наявного робочого комп’ютерного обладнання викладачів;

- перевірка наявного робочого комп’ютерного обладнання студентів;

- створення розкладу-графіка онлайн-занять;

- добір форми контролю виконання студентами завдань;

- добір інструментів для оцінювання навчальних досягнень студентів;

- пошук якісного цифрового освітнього контенту;

- термінове навчання педагогів використання цифрових засобів для здійснення дистанційного навчання [7].

Якість викладання значною мірою залежить і від рівня підготовки викладача, опанування ним сучасної методики викладання та володіння мультимедійними технологіями навчання. Ефективність засвоєння курсу дисципліни значно підвищується завдяки впровадженню мультимедійних технологій, можливості яких натепер важко переоцінити [8, с. 62].

Таким чином, дистанційна форма навчання нині не лише набуває неабиякої популярності, а й, безперечно, є потребою часу. Для неї характерні такі особливості: індивідуальний режим; домінування самостійної пізнавальної діяльності; створення спеціальних дидактичних матеріалів для самостійної роботи; зміна функцій тренера (організація, керівництво, загальна орієнтація у навчальному матеріалі, консультування, контроль); зміна позиції слухача (ініціативність у режимі роботи над навчальним матеріалом, самостійне 
Електронне наукове фахове видання «Адаптивне управління: теорія і практика.

Серія «Педагогіка»

Випуск 10(19), 2020

планування своєї роботи, відповідальність за виконання намічених планів тощо).

Тобто сучасні інформаційні освітні технології руйнують традиційні лінійні зв’язки, замінюючи їх на сучасні, мережеві.

Навчання онлайн забезпечує комплексне вивчення дисциплін для підготовки бакалаврів готельно-ресторанної справи відповідно до нової навчальної програми. При цьому на платформі пропонуються не розрізнені завдання, a повноцінно укомплектоване заняття (тобто теоретичний i практичний матеріал), яке включає:

- тестові завдання різних рівнів і видів, які допомагають студентам усвідомити основні поняття теми та зв’язки між ними, перевірити розуміння основних питань теми, здійснити самоконтроль, навчитися розв'язувати найпростіші завдання, що стосуються такої теми;

- відео, яке переривається запитаннями до студентів (це сприяє усвідомленому засвоєнню матеріалу, концентрації уваги, розвитку постійного самоконтролю і самокорекціï);

- опорні схеми, що демонструють зв’язки між поняттями теми та дають можливість швидко відтворити все те, про що йдеться у відео, і що необхідно буде для розв’язування завдань;

- завдання на відповідність, сортування, знаходження помилок та введення відповіді, що спрямовані на використання набутих на практиці знань, зокрема й у змінених умовах.

Висновки. Таким чином, реалізація інноваційних технологій в освітньому процесі впливає та активізує сучасний розвиток закладів освіти, спрямовує здобувати відповідні фахові компетентності, вміння та навички у взаємозв'язку між всіма суб'єктами та об'єктами освітнього процесу, є пріоритетною основою інноваційних упроваджень в освіті. Застарілі підходи до викладання $\epsilon$ основною перешкодою до їх творчого, індивідуального та професійного розвитку. Отже, використання в педагогічному процесі технологіі реалізації 
Електронне наукове фрахове видання «Адаптивне управління: теорія і практика.

Серія «Педагогіка»

Випуск 10(19), 2020

інтерактивного навчання $є$ необхідною умовою оптимального розвитку і тих, хто навчається і тих, хто навчає.

Головними критеріями оцінки ефективності освітніх послуг ЗВО сьогодення мають бути не якість планування та організації навчального процесу, а результати освіти: отримані бакалаврами готельно-ресторанної справи знання, компетенції та навички, рівень фахової підготовки, інтелігентність, здатність до саморозвитку, самовдосконалення та самоосвіти.

\section{СПИСОК ВИКОРИСТАНИХ ДЖЕРЕЛ:}

1. Галиця I. Інтелектуально-конкурентні ігри як креативний механізм активізації педагогічного, наукового та інноваційного процесів / I. Галиця, О. Галиця / Вищза школа. - 2011. - №1.

2. Інноваційні педагогічні технології: теорія та практика використання у вищій школі : монографія / I. І. Доброскок, В. П. Коцур, С. О. Нікітчина [та ін.] Переяслав- Хмельниц. держ. пед. ун-т ім. Г. Сковороди, Ін-т пед. освіти і освіти дорослих АПН України. - Переяслав-Хмельниц. : Вид-во С. В. Карпук, 2008.

3. Інновації у вищій освіті: проблеми, досвід, перспективи : монографія / П. Ю. Саух [та ін.] ; ред. П. Ю. Саух. - Житомир : Вид-во ЖДУ ім. І. Франка, 2011.

4. Кашинська О.С. Використання веб-квестів у процесі підготовки студентів спеціальності «Готельно-ресторанна справа». Вісник Луганського національного університету імені Тараса Шевченка. Серія «Педагогічні науки». 2017. № 1(2). С. 108-115.

5. Кудла Н.С., Мандро Х.М., Мошура Д.А. Ринкові вимоги до підготовки фахівців готельно-ресторанної сфери. Інновації, тренди та перспективи індустріі гостинності : матеріали I Міжнародної науково-практичної конференції (м. Львів, 12 грудня 2019 р.). Львів : ЛТЕУ, 2019. 192 с. С. 135-138.

6. Lytvynova S., Melnyk O. Professional Development of Teachers Using Cloud Services During Non-formal Education. Proc. of 1st Workshop 3L-Person'2016 (Kyiv, Ukraine, June 21-24, 2016). 2016. Pp. 648-655. URL: http://ceur-ws.org/Vol1614/ paper_51.pdf (дата звернення: 18.09.20).

7.Лисенко М. В. Інноваційна парадигма вищої освіти України за умов переходу до інформаційного суспільства : автореф. дис.канд. філос. наук : 09.00.10; М-во освіти і науки, молоді та спорту України, Нац. техн. ун-т України «Київ. політехн. ін-т». - К., 2013.

8.Палій В. Проведення лекцій на основі мультимедійних технологій. Фахова передвища освіта. Київ, 2019. № 1(48). С. 62-63.

9.Проблеми впровадження дистанційної освіти в Україні. URL: http://edu.minfin.gov.ua/LearningProcess/RemoteEducation/Pages/Проблемивпровадження дистанційної освіти в Україні.aspx (дата звернення:18.09.2020).

(C) Українська інженерно-педагогічна академія

(C) ГО «Школа адаптивного управління соціально-педагогічними системами»

(C) Каролоп $O$. 
10.Про затвердження Положення про дистанційне навчання : Наказ $\mathrm{MOH}$ України від 25 квітня 2013 р. № 466. URL: http://zakon0.rada.gov.ua/laws/ show/z0703-13 (дата звернення: 18.09.2020).

11.Про Національну стратегію розвитку освіти в Україні на період до 2021 p. : Указ Президента України від 25 червня 2013 р. № 344/2013. URL:

https://zakon.rada.gov.ua/laws/show/344/2013\#Text (дата звернення: 18.09.2020).

12. Сисоєва С.О. Інтерактивні технології навчання дорослих: навчальнометодичний посібник / С.О. Сисоєва; НАПН України, Інт. педагогічної освіти і освіти дорослих. - К.: ВД “ЕКМО”, 2011. - С. 320.

13.Щодо організації дистанційного навчання в закладах загальної середньої освіти під час карантину. URL: https://cutt.ly/dyB9CuF (дата звернення: 18.09.20).

\section{REFERENCES}

1. Dobroskok, I.I., Kotsur, V.P., Nikitchina, S.O. [and others] (2008). Innovatsiini pedahohichni tekhnolohii teoriia ta praktyka vykorystannia $u$ vyshchii shkoli monohrafiia [Innovative pedagogical technologies: theory and practice of use in higher school: monograph]. Pereyaslav-Khmelnits. state ped. Univ. Of Skovoroda, G., Inst. Of Ped. education and adult education of the Academy of Pedagogical Sciences of Ukraine. - Pereyaslav-Khmelnytsky: Published by S.V. Karpuk. (in Ukrainian)

2. Halytsya, I. (2011). Intelektualno-konkurentni ihry yak kreatyvnyi mekhanizm aktyvizatsii pedahohichnoho, naukovoho ta innovatsiinoho protsesiv [Intellectualcompetitive games as a creative mechanism of activation of pedagogical, scientific and innovative processes]. Higher school, №1. (in Ukrainian)

3. Kashinskaya, O. E. (2017). Vykorystannia veb-kvestiv u protsesi pidhotovky studentiv spetsialnosti «Hotelno-restoranna sprava» [The use of web-quests in the process of preparing students for the specialty "Hotel and restaurant business"]. Bulletin of Luhansk Taras Shevchenko National University. Series "Pedagogical Sciences". № 1 (2), 108-115. (in Ukrainian)

4. Kudla, N.E., Mandro, H.M., Moshura, D. A. (2019). Rynkovi vymohy do pidhotovky fakhivtsiv hotelno-restorannoi sfery. Innovatsii, trendy ta perspektyvy industrii hostynnosti: materialy i mizhnarodnoi naukovo-praktychnoi konferentsii $(\mathrm{m}$. Lviv, 12 Hrudnia 2019 r.). [Market requirements for the training of hotel and restaurant specialists. Innovations, trends and prospects of the hospitality industry: materials of the $1^{\text {st }}$ International scientific-practical conference (Lviv, December 12, 2019)]. Lviv: LTEU. 192 p., 135-138. (in Ukrainian)

5. Lysenko, M.V. (2013). Innovatsiina paradyhma vyshchoi osvity ukrainy za umov perekhodu do informatsiinoho suspilstva: avtoref. dys. kand. filos. nauk 09.00.10. [Innovative paradigm of higher education in Ukraine in terms of transition to the information society: author. Candidate of Dissertation philos. Science:

\footnotetext{
(C) Українська інженерно-педагогічна академія

(c) ГО «Школа адаптивного управління сочіально-педагогічними системами»

(C) Каролоп 0 .
} 
09.00.10]. Ministry of Education and Science, Youth and Sports of Ukraine, Nat. tech. University of Ukraine "Kyiv. Polytechnic Inst". - K. (in Ukrainian)

6. Lytvynova, S., Melnyk, O. (2016). Professional Development of Teachers Using Cloud Services During Non-formal Education. Proc. of 1st Workshop 3LPerson'2016 (Kyiv, Ukraine, June 21-24, 2016). 648-655. Retrieved from: http://ceur-ws.org/Vol-1614/ paper_51.pdf (access date: 18.09.20).

7. Pro natsionalnu stratehiiu rozvytku osvity v Ukraini na period do $2021 \mathrm{r}$. [On the National Strategy for the Development of Education in Ukraine for the period up to 2021]. Decree of the President of Ukraine of June 25, 2013 № 344/2013. Retrieved from: https://zakon.rada.gov.ua/laws/show/344/2013\#Text (access date: 18.09.2020). (in Ukrainian)

8. Pro zatverdzhennia polozhennia pro dystantsiine navchannia [On approval of the Regulation on distance learning]. Order of the Ministry of Education and Science of Ukraine of April 25, 2013 № 466. Retrieved from: http : // zakon 0. rada. gov . ua / laws / show / z0703-13 (access date: 18.09.2020). (in Ukrainian)

9. Problemy vprovadzhennia dystantsiinoi osvity $v$ Ukraini [Problems of introduction of distance education in Ukraine]. Retrieved from: http : // edu.minfin.gov.ua/ LearningProcess/RemoteEducation / Pages /Problems of implementing distance education in Ukraine.aspx (access date: 18.09.2020). (in Ukrainian)

10. Pyro, A.V. (2019). Provedennia lektsii na osnovi multymediinykh tekhnolohii. [Lectures based on Multimedia technology]. Professional higher education. Kyiv, № 1 (48). 62-63. (in Ukrainian)

11. Saukh, P. Yu. (and others) [ed.] (2011). Innovatsii u vyshchii osviti, problemy, dosvid, perspektyvy: monohrafiia [Innovations in higher education: problems, experience, prospects: monografiia]. Zhytomyr: ZhSU Publishing House of I. Franko. (in Ukrainian)

12. Shchodo orhanizatsii dystantsiinoho navchannia $v$ zakladakh zahalnoi serednoi osvity pid chas karantynu. [As for distance education in institutions of secondary education at Karan fence]. Retrieved from: https : // cutt . ly / dyB $9 \mathrm{CuF}$ (access date: 18.09.20). (in Ukrainian)

13. Sysoeva, S. O. (2011). Interaktyvni tekhnolohii navchannia doroslykh: navchalno-metodychnyi posibnyk [Interactive technologies of adult education: educational - methodical manual]. NAPS of Ukraine, Int. pedagogical education and adult education. - К.: ВД “ЕКМО”, 320. (in Ukrainian) 


\section{КАРОЛОП ЕЛЕНА,}

ст. преподаватель Учебно-научного института

Национального университета культуры и искусств, Киев, Украина

\section{Инновационные подходы к формированию и развитию профессиональной компетентности будущих бакалавров гостинично-ресторанного дела}

Аннотация. В статье раскрыта проблема инновационных подходов относительно профессиональной подготовки бакалавров, рассматриваются инновационные методы обучения, которые используются в системе современного образовательного процесса, определенны особенности средств, форм и методов инновационного обучения, раскрывается специфика их использование в образовательном процессе.

Акцентируется внимание на инновационных подходах относительно формирования профессионально активных бакалавров гостиничноресторанного дела через использование интерактивных методов обучения в УВО. Интерактивные занятия в форме тренингов (позиционно-ролевых) активизируют развитие профессиональной креативности, мобильности студентов, реализуют практику опережающей профессиональной подготовки бакалавров, сделан акцент на необходимости использования мультимедий как средства и кейс-технологии, как метода обучения Профессиональная компетентность рассматривается как средство, как образ и как результат освоения новаций бакалаврами гостинично-ресторанного дела, которые сознательно приобщаются к инновационной деятельности и соответственно подготовленные к ней.

Внедрение инновационных технологий в образовательный процесс, в частности в ходе дистанционного обучения, содействует повышению эффективности образования, а как следствие, качественной подготовке будущих специалистов.

Ключевые слова: инновационные подходы, профессиональная компетентность, бакалавры, гостинично-ресторанное дело, инновационные технологии, дистанционное обучение. 


\section{KAROLOP OLENA,}

Art. vicladach of the Naval Science Institute

National University of Culture and Arts, Kiev, Ukraine

\section{Innovation go to the formulation and development of professional competence of the Maybut bachelors of the hotel and restaurant service}

Annotation. The article reveals the problem of innovative approaches to professional training of bachelors, considers innovative teaching methods used in the modern educational process, identifies features of means, forms and methods of innovative learning, reveals the specifics of their use in the educational process.

Emphasis is placed on innovative approaches to the formation of professionally active bachelors in hotel and restaurant business through the use of interactive teaching methods in freelance education. Interactive classes in the form of trainings (position-role) intensify the development of professional creativity, student mobility, implement the practice of advanced professional training of bachelors, emphasis on the need to use multimedia as a tool and case technology as a teaching method. as a result of mastering of innovations by bachelors of hotel and restaurant business who consciously join innovative activity and are accordingly prepared for it.

The introduction of innovative technologies in the educational process, in particular during distance learning, contributes to improving the efficiency of education, and as a consequence, better training of future professionals.

Key words: innovation, professional competence, bachelor's degree, hotel and restaurant on the right, innovation technology, distance learning. 